\title{
Juan Negro
}

\section{Poemas del verano}

\section{LA ORUGA}

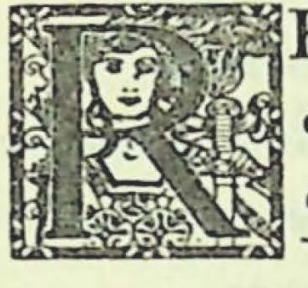

EPTA, repta largamente la oruga dejando una vibración de pelos rojos en el alto verano.

$Y$ atentamente las encinas las escuchan pasar hasta el fondo de sus raices, y los olmos la escuchan pasar y las mazorcas nuevas [del maiz. A la oruga que repta también a través de mi corazón como si éste fuese una manzana de su propiedad, o un ramo de espino o de duraznero. Esa oruga listada como la piel de un 'acordeón que se hiciese callar a si mismo en los largos dias [solares, caminando sin prisa entre las hierbas Je olor y los [grillos mudos, pasando y repasando su escobillón abigarrado por los grandes frutos del mediodia y la siesta, por los minutos, por mi sangre, por la atmósfera que late entonces y se hace oir hasta el fondo de las [raices de una desmelenada encina por cuya hoja más pequeña repta y repta ahora largamente la oruga sin cansarse. 


\section{DOLOR FISICO}

El verano camina con pasos de fruta.

El verano que abre las azucenas y los balnearios, que empuja el mar hasta las pupilas de las ciudades Y hace gritar a las lechuzas en las noches de amor. El estío hollando los surcos que ya dieron su grano, rompiendo las puertas empecinadamente cerradas, invitando a correr bajo un sol de amplios brazos. El mismo verano que abre un pozo sobre los nervios [de mi frente para colocar alli una inmóvil ávispa de dolor; el talón de una semilla que cava sin descanso mientras las sienes laten como timpanos al viento. El verano con el rostro rayado de arañas y de grillos, pesarto como la flor del zapallo y rojo $y$ verde contemplándose en el espejo vivo de los crepúsculos; rizando el pelo de las hierbas y de los mamiferos, batiendo ramas y prolongadas lenguas con sed, acumulando en los cauces las lágrimas de la nieve, Y siempre, siempre colocando sobre los nervios de mi [frente

el aguijón de una avispa que cava sin descanso. Cuando la tarde se aleja con pasos de fruta o cuando irrumpen las mañanas de limpios ojos, en el verano que se recuesta ahora sobre esta página. 